\section{Design adds value}

Sir: Bob Allies' thoughtful leader (arq vol.1: no.1) implies that UK National Lottery rules force applicants for buildings to focus on superficial images rather than on considered designs, in their scramble to impress funding bodies. If this was true in the beginning (the Lottery has only been running for a year), it is certainly a diminishing tendency nowadays. There are several reasons for this.

First, the distributor bodies have become more sophisticated in their reading of the Government's rules which require them to assess design quality in Lottery capital projects. The process of architectural assessment is less of a scramble. There are more professional assessors to advise.

Second, there is a greater awareness among the distributors that early design thinking adds value. In other words, hostility to architecture as a 'back-door' beneficiary of the Lottery has been replaced by tolerance and a willingness to promote good design ideas.

Third, at a technical level, the distributors are discovering that what they called 'feasibility studies' (which the arts bodies, especially, are willing to pay for) should be distinguished from 'design development' (to which in most cases they are also willing to contribute). This distinction alone will help reduce the amount of hasty and superficial work submitted, and for which there was plenty of evidence in the first batch of Lottery applications.

In the early months of the Lottery these two separate processes were lumped together. The result was that applicants rushed off, appointed elaborate professional design teams and together stampeded into detailed design. This frequently preceded a mature understanding of what it was, precisely, they wished to achieve with a building. The results of doing things in the wrong order (instead of briefing first, then design) have been measured by disappointed architects whose projects, on behalf of their clients, eventually failed other Lottery tests of viability, including business planning and revenue funding. The result is of course abortive design work, which nobody wishes to see. The best Lottery design rule is fesfina lente hasten slowly.

Rory Coonan

London SW1

Rory Coonan is architect of the Design Quality Standards for Lottery Projects and formerly Head of Architecture at the Arts Council.

\section{Nature, Modernism and Modernity} Sir: I read with admiration Richard Weston's scholarly review of the conference which I convened at the University of East London on 'Rethinking the architecture/landscape relationship' (arq vol. 1: no. 4). But I have slowly come to the conclusion that Weston's view is based on a fundamental misconception.

Of course it seems obvious that Fallingwater stands in a different relationship to the surrounding landscape than does the Villa Savoye. But this is obvious only when one considers appearances. When one analyses in depth the conceptions behind these appearances, then Wright's organicism starts to merge conceptually into Corbu's Ruskinian love for nature. This Ruskinian influence has been widely documented (Sekler, Constant, Green, Turner, von Moos and others).

Therefore the notion that Wright gives us continuity with nature but
Corbu does not, is based on simplistic appearances. Both Savoye and Fallingwater use strategies from the Modernist tool-box: the wall that connects interior and exterior, the window that frames the quasiwilderness and the columns that raise the building. Why? Because these design strategies highlight 'Nature' as if untouched by human hand. The whole point is that these strategies create a sense of untouched quasiwilderness. They in fact 'build the site' in a conceptual way: they create the very sense of 'Nature'.

In this respect, the notion of intrinsic value of a simple continuity between inside and outside seems to me trite. The Jacobs House II and the Marseilles roof-top reveal the same conceptual construction of 'Nature'. This specific construction of 'Nature' stands to Modernist architecture as 'the primitive' stands to Modernist art This construction of 'Nature' is in fact 'the primitive' of Modernist architecture. But it is not enough to say so (as in Elizabeth K. Meyer's work) since 'the primitive' is but a label whose multiple and complex meanings must be archivally investigated and proved. This creates a real methodological challenge.

From this, I draw three conclusions. First, architectural history must become more conversant with the analytic techniques of art history. Until such time, architectural history will not re-establish the significance it had until the early twentieth century for and within cultural history. Second, conceptualisations of 'nature' and of landscape provide a new theoretical perspective which reveals architecture in a new light. As with the feminist perspective or the post-colonialist perspective, one is not trying to 
arq: Vol 2: autumn 1996

letters

establish a single truth but to reveal new aspects: I like to use the image of changing lenses to photograph the same scene.

Third, concepts of 'nature' are fundamental to understand Modernism, Modernity and the modern. It is not for nothing that Viollet-le-Duc's main passion was. mountains: mountain-walking, geological mountain research, sketching mountains and painting mountains. And the Villa Mandrot is contemporaneous with the Villa Savoye. It is thus not the case that there are no Modernist garden masterpieces: I would say that the Villa Savoye offers one archetypal Modernist garden in which the traditional English Landscape Garden is transcribed to become the Modernist Garden Landscape. Jan Birksted

London

Jan Birksted teaches at the University of East London and is the co-ordinator for Landscapes and Gardens within DOCOMOMO

Letters, should be typed doublespaced and sent to Peter Carolin, Architectural Research Quarterly, C/o University of Cambridge Department of Architecture, 1 Scroope Terrace, Cambridge, CB2 1PX, faxed to +44 (0)1223 332960 , or e-mailed to pc207@hermes.cam.ac.uk The editor reserves the right to shorten letters.

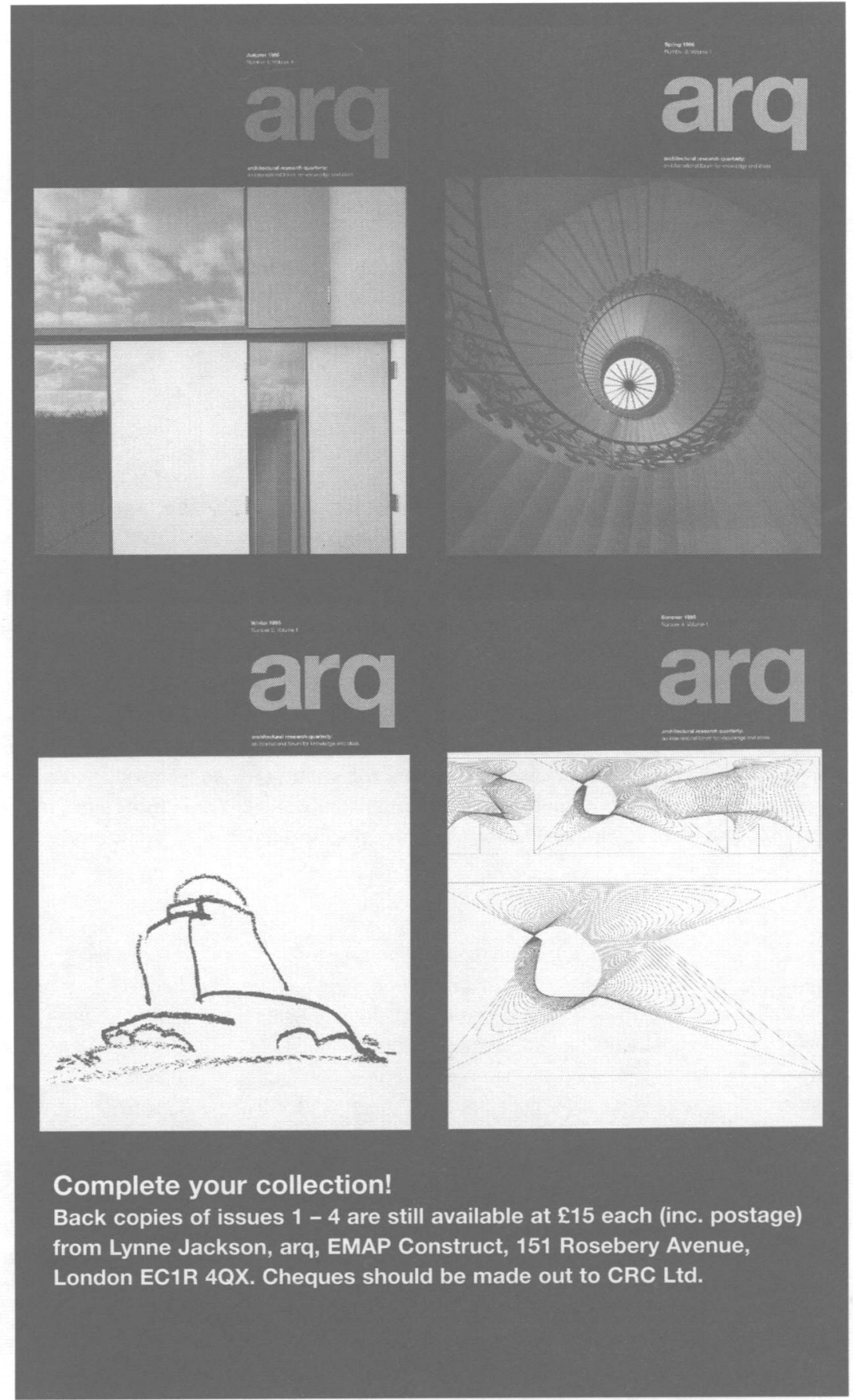

letters 